\title{
Population Ecology of British Shrews in Grassland
}

\author{
John, C. PERNETTA ${ }^{1}$
}

\begin{abstract}
Pernetta J. C., 1977: Population ecology of British shrews in grassland. Acta theriol., 22, 20: 279-296 [With 5 Tables \& 8 Figs.]

The results of 25 months of live trapping common and pigmy shrews in a grassland habitat on the Oxford University Estate at Wytham, England are presented together with data from an 18 month snap trapping programme in a similar habitat nearby. The activity of the two Sorex species in the wild is described and various population parameters such as breeding condition, litter size, density and dispersal are given. A method of age determination is detailed which permits more accurate ageing than previously possible. On the basis of these data, some suggestions are made concerning the mechanism and magnitude of population processes in these animals.

[Dept. Zool. Anim. Ecol. Res. Group, South Parks Road, Oxford OX1 3PS, England].
\end{abstract}

\section{INTRODUCTION}

The work reported in this paper is concerned with the population ecology of Sorex araneus and Sorex minutus based on live trapping data. Data from animals snap-trapped as part of a dietary study (P e r n e t t a, 1973a, 1976b) are used here in the analysis of population age structure, details of lateral flank glands, breeding conditions, and embryo numbers. To avoid interference between the live and snap-trapping programmes, they were conducted in separate areas of the Oxford University Estate at Wytham, England.

\section{MATERIALS AND METHODS}

\section{The Wytham Study Areas}

Trapping was conducted on two areas of rough grassland known as Rough Common and Upper Seeds where thin soil cover overlies the limestone cap of Wytham hill. Upper Seeds is not subject to interference by man, however, selected portions of Rough Common are periodically cleared of scrub growth. Rough Common is bounded by woodland and a muddy cart track; Upper Seeds is enclosed.on three sides by mixed deciduous woodland of: chestnut (Castanea sativa Mill.), ash

1 Present address: Dept. Zool. Univ. Manitoba, Winnipeg, Manitoba, R3T 2N2, Canada. 
(Fraxinus excelsior L.), birch (Betula pubescens Ehrh.), sycamore (Acer pseudioplatanus L.), beech (Fagus sylvatica L.), and oak (Quercus sp. L.); and on the fourth side by an arable field and small coniferous copse.

The dominant plants of both areas are Brachipodium pinnatum and the bramble (Rubus fruticosus agg.), whilst on parts of Rough Common are large patches of bracken (Pteridium aquilinum L.). Upper Seeds has recently developed a high density $(\bumpeq 4,000 / \mathrm{Ha})$ of shrub sized bushes and trees including hawthorn (Crataegus monogyna Jacq.), ash (F. excelsior) and wild rose (Rosa sp. L.), with a few other deciduous saplings such as oak and sycamore.

In general the ground flora includes grassland species such as teasel (Dipsacus fullonum L.), bedstraws (Galium sp. L.), primrose (Primula vulgaris Huds.), cowslip (Primula veris L.), violet (Viola sp. L.), self-heal (Prunella vulgaris L.) and various large umbellifers.

The presence of the dominant grass B. pinnatum results in a layering of the air-ground interface. The slow rate of decomposition of this grass results in a mat of partially decayed stems and leaves below the current years growth. Examination showed small mammal runs in the mat itself, on its surface, and below it on the soil surface.

\section{Trapping Techniques}

The most frequently used live trap in Britain is the Longworth trap designed by Chitty and Kempson of the Bureau of Animal Populations, Oxford (Chitty \& Kempson, 1949). During the present work one modification was used, namely a mouse excluder following the design of $\mathrm{Cr}$ ow croft (1951); this small metal phlange fits snugly into the tunnel of the trap and its $1 / \mathbf{2}^{\prime \prime}$ diameter hole excludes mice and voles whilst permitting shrews to enter. Its use reduces the time wasted handling small rodents and increases the number of traps available to the shrews. On two occasions slow worms (Anguis fragilis L.) were caught in traps fitted with such an excluder.

Michiels on (1966) working on common and pigmy shrews in Holland found that trap success was increased if bait was added to the traps. C r ow croft (1951) used no bait and emptied the traps every two hours to prevent trap deaths. During the present study a moist mixture of chopped heart and liver $(3: 1)$ was placed in the nest box, and trap success was found to be higher when it was present (Fig. 1). This figure also shows that an initial avoidance response is present, contrary to the findings of $\mathrm{Crow}$ croft (1951) but in accordance with those of $\mathrm{Michiels}$ o $\mathrm{n}$ (1966) and Pucek (1969). The former worker adopted a prebaiting period and during the present work a period of one day was used. Traps were visited at 0800 , 1600 and 2400 hours, and only two trap deaths occurred out of 734 captures.

100 traps were arranged at $12 \mathrm{~m}$ intervals in the form of an L-shaped grid covering an area of $8,064 \mathrm{~m}^{2}$ (approx. half the area of Upper Seeds). Trapping was conducted for a six day period once a month from December, 1969 through to January, 1972, marking was by toe clipping. The shape of the grid was dictated by the habitat, following the boundaries of the grassland on three of its sides.

McGill »alsteel s snap traps, baited with peanut butter were used to collect animals for dietary analysis (P ernetta, 1976b), other data from these animals are presented here. These traps were arranged in two grids $100 \mathrm{~m}$ by $40 \mathrm{~m}$, at $10 \mathrm{~m}$ intervals, and located on different parts of Rough Common for 10 days each month, from May, 1970 to January, 1972. 

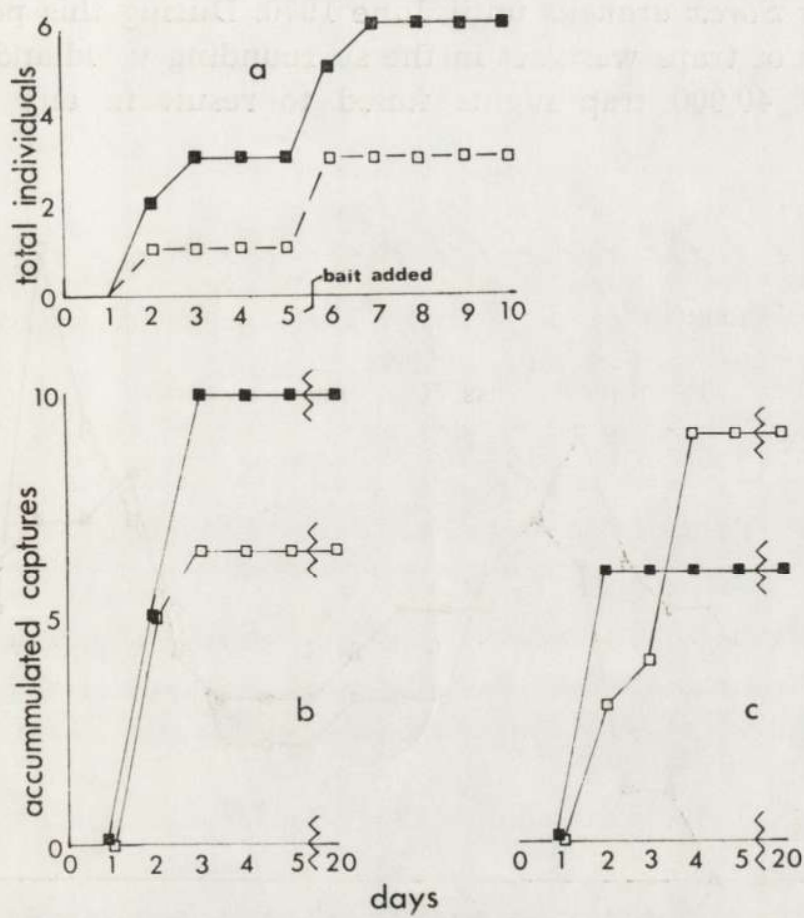

Fig. 1. Sample trap results,

S. araneus, $\square$ S. minutus.

(a) effects of adding bait to Longworth live traps. (b) removal captures, 4 th -25 th May, 1970. (c) removal captures, 30th March-19th April, 1971.

\section{RESULTS}

\section{Live Trap Results}

Highest resaptures; 4.4/trap period and 4.9/trap period for $S$. araneus and $S$. minutus respectively, were obtained during the winter months from October to March (Fig. 2). Lowest recaptures; 2.4/trap period and $2.1 /$ trap period for $S$. araneus and $S$. minutus respectively, were obtained during the spring and summer period from April to September. Since naturally occuring food sources are generally more abundant during the spring and summer, these figures suggest that recapture success may by the result of an exploratory drive motivated by hunger and modified by territoriality.

Peak numbers of both species (Fig. 2) occur in the summer followed by a decline to the steady prebreeding level, achieved by January or February. The sudden decline in numbers observed during February and March, 1970, is somewhat puzzling (it was not due to trap deaths). The 
grid was then invaded by new individuals of $S$. minutus but was not recolonised by Sorex araneus until June 1970. During this period of low numbers grids of traps were set in the surrounding ${ }^{\cdots}$ odland but a total trap effort of 40,000 trap nights failed to result i.. any captures of S. araneus.
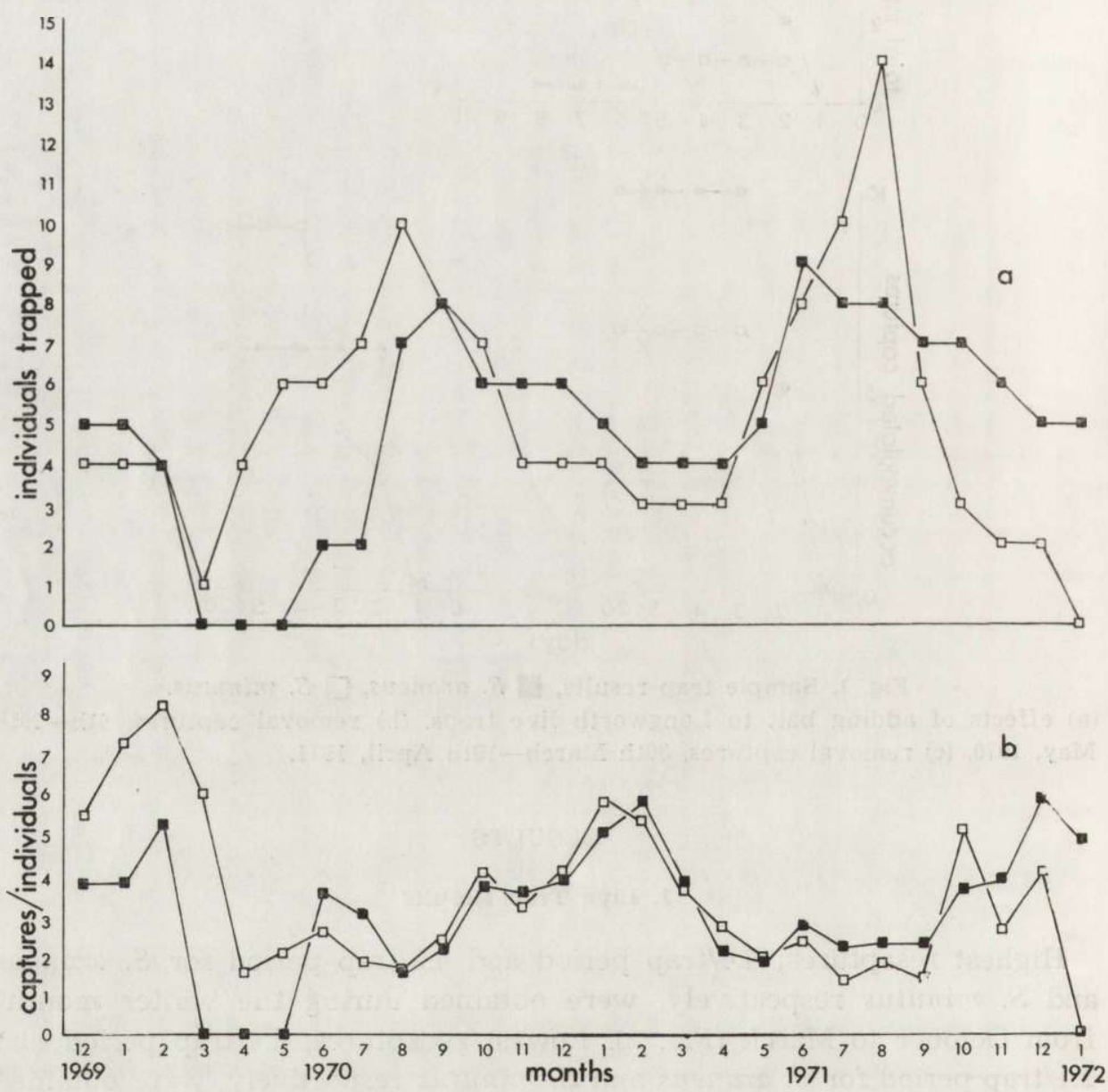

Fig. 2. Live trap results, $\quad$ S. araneus, $\square$ S. minutus, in Wytham grassland, December, 1969 - January, 1972.

(a) numbers of individuals caught each month. (b) average number of recaptures during each period.

\section{Activity}

Traps were visited three times a day and the accompanying Figure 3 shows the numbers of captures of $S$. araneus and $S$. minutus made at these times. Captures indicate patterns of activity similar to those noted 
by Crowcroft (1954), Janský \& Hanák (1960), Gę bc zyński (1965) and Buchalczyk (1972).

If the year is divided into an arbitrary summer and winter the latter starting at the beginning of November and ending at the end of April, and the captures summed for these two periods, then in the case of the common shrew the distribution of captures for the two periods is not noticeably different. In the case of the pigmy shrew, however, activity during the daylight hours of winter $(0800-1600)$ is higher than during the same period in summer. In summer, peak activity occurs between 1600 and 2400 hours, and is markedly greater than between

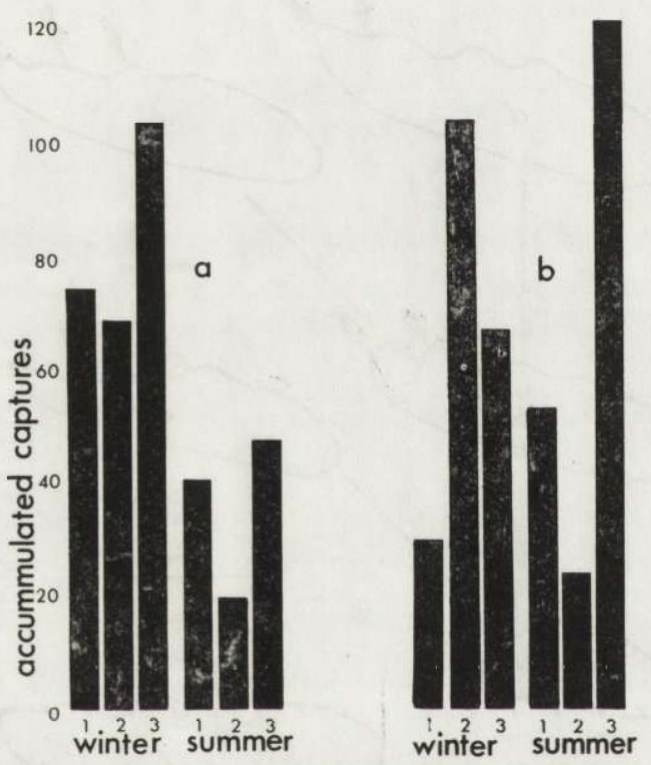

Fig. 3. Winter and summer captures of, (a) $S$. araneus and (b) $S$. minutus, during the three trapping periods; $0000-0800$ hours (1); $0800-1600$ hours (2); $1600-2400$ hours (3).

2400 and 0800 . During the summer, much of the period from 1600 to 2400 is in fact, light, thus activity may be occuring during the daylight rather than at night.

\section{Age Structure and Ageing Techniques}

A d a m s $(1910,1912)$ and C r o w c r of t (1956) have shown that during most of the year no more than one generation is present in shrew populations. The ageing techniques used by $\mathrm{Crowcroft}(1956)$ and by many authors (Bis hop \& Delany, 1963; C on aw a y, 1952; R ood, 1965), namely the height of the lower canine is not sufficiently sensitive to divide animals into more than year classes. 
The possibility of more accurate ageing was investigated using four measurements of the lower incisors of snap trapped individuals (Fig. 4), the values of the four measurements taken by means of a monocular microscope with fitted eyepiece graticule, were summed and the resultant figure used in the analysis.

Fig. 5 shows values of this index for animals trapped in Wytham grassland. The index follows a linear decrease up to February after which two groups appear among the adults. Old animals caught during the late summer frequently had extremely small values for this index. Exami-

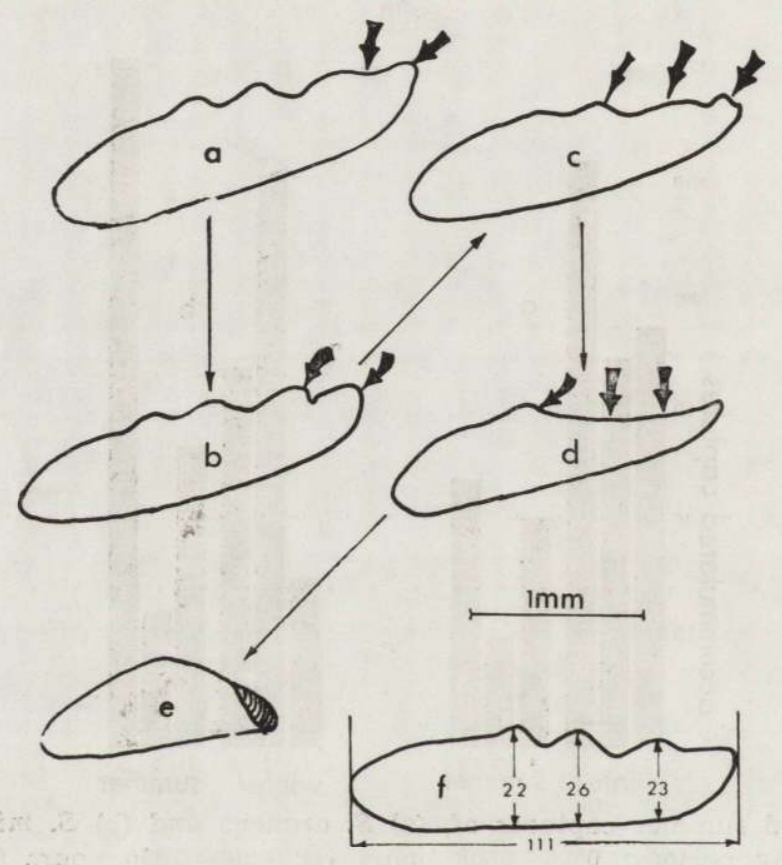

Fig. 4. Progressive wear of the anterior lower incisor of $S$. araneus a-e: f, measurements taken to determine wear indices used in age analysis.

nation of these and other animals showed that as wear progresses the anterior portion of the tooth becomes thin and susceptible to breakage (Fig. 4). No adults were caught after June in which such breakage had not occurred and it is apparent amongst some juveniles from October onwards.

Table 1 gives comparative values for samples of $S$. araneus and shows wear to be different from snap trapped samples of the same age classes from different localities.

When values of this index for a sample of young of the year trapped 
during late September early October in a bracken/bramble habitat on Bardsey Island, North Wales, are plotted on probability paper following the method of $\mathrm{H}$ arding (1949) for small samples, it is apparent that two groups of juveniles are present (Fig. 6a). Such a detailed analysis

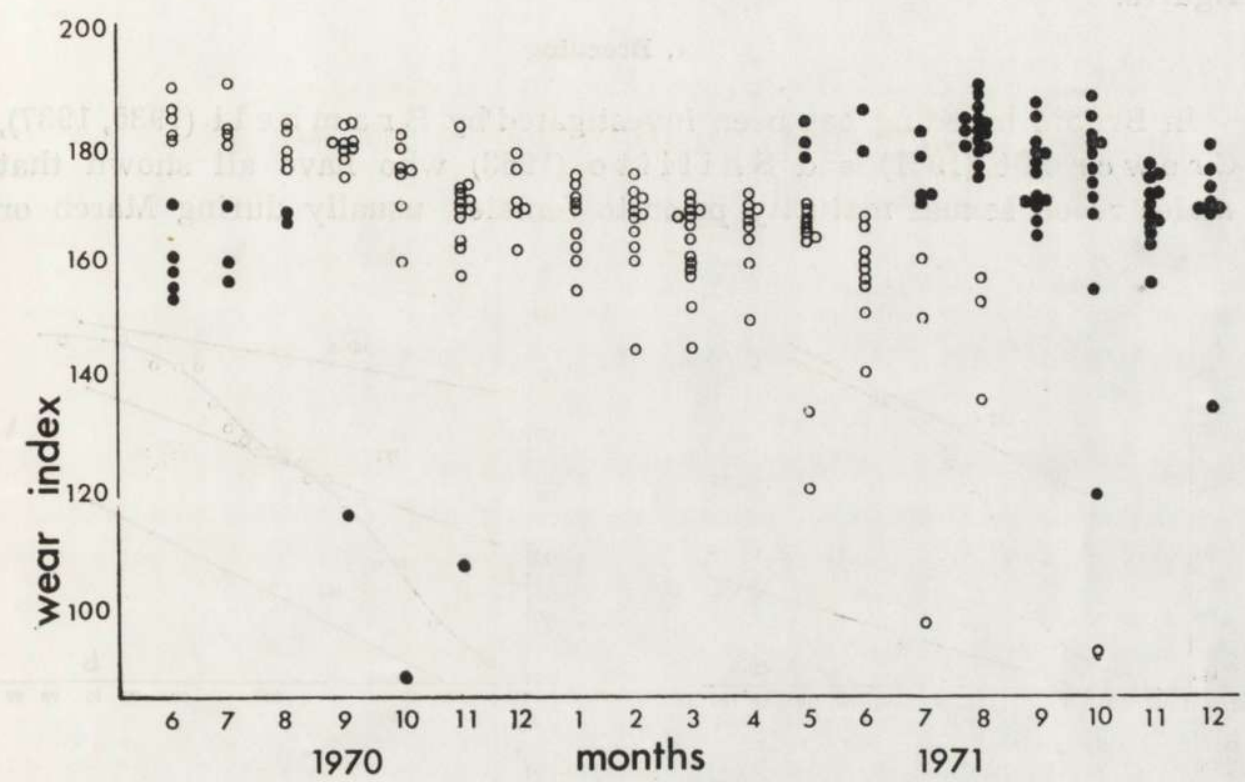

Fig. 5. Values of wear index for $S$ araneus snap trapped in Wytham grassland from June, 1970 to December, 1971.

(51 wear index units $=1 \mathrm{~mm}$ ).

Table 1

Mean tooth wear index $( \pm$ S.E.) for $S$. araneus from different localities, (Figures in parenthesis, individual values)

\begin{tabular}{llccrr}
\hline \multicolumn{1}{c}{ Locality } & \multicolumn{1}{c}{ Date } & \multicolumn{2}{c}{ Wear indices } & n \\
\hline Maer Hills, Staff. & May, 1971 & $(109)$ & $(141)(146)$ & $159.0 \pm 4.0$ & 23 \\
Wytham, Berks. & May, 1971 & $(121)$ & $(134)$ & $165.8 \pm 0.8$ & 7 \\
Odiham, Hants. & October, 1971 & $162.0 \pm 4.4$ & $173.0 \pm 3.3$ & $181.5 \pm 1.4$ & 21 \\
Bardsey, N. Wales & October, 1971 & $165.0 \pm 1.0$ & $172.0 \pm 1.5$ & & 12 \\
Wytham, Berks. & October, 1971 & $(160)$ & $173.0 \pm 2.1$ & & 5 \\
\hline
\end{tabular}

of the cohort relationships is really only useful when applied to large samples from the same habitat and locality, collected in a short time period. Three further samples are included to show the value of the methods. In Fig. 6c, it would appear that two cohorts are present, and 
three in $6 \mathrm{~b}$. In Fig. $6 \mathrm{~d}$, the data appear to fit a straight line suggesting the presence of only one cohort. It may be that breeding was, during this year and in this locality, less synchronous than is normal in this species. A suggestion supported by the large spread of values for the index when compared with the spread shown by cohorts in the other figures.

\section{Breeding}

In Britain breeding has been investigated by B r a m be $11(1935,1937)$, Crowcroft (1951) and Shillito (1963) who have all shown that males reach sexual maturity prior to females, usually during March or
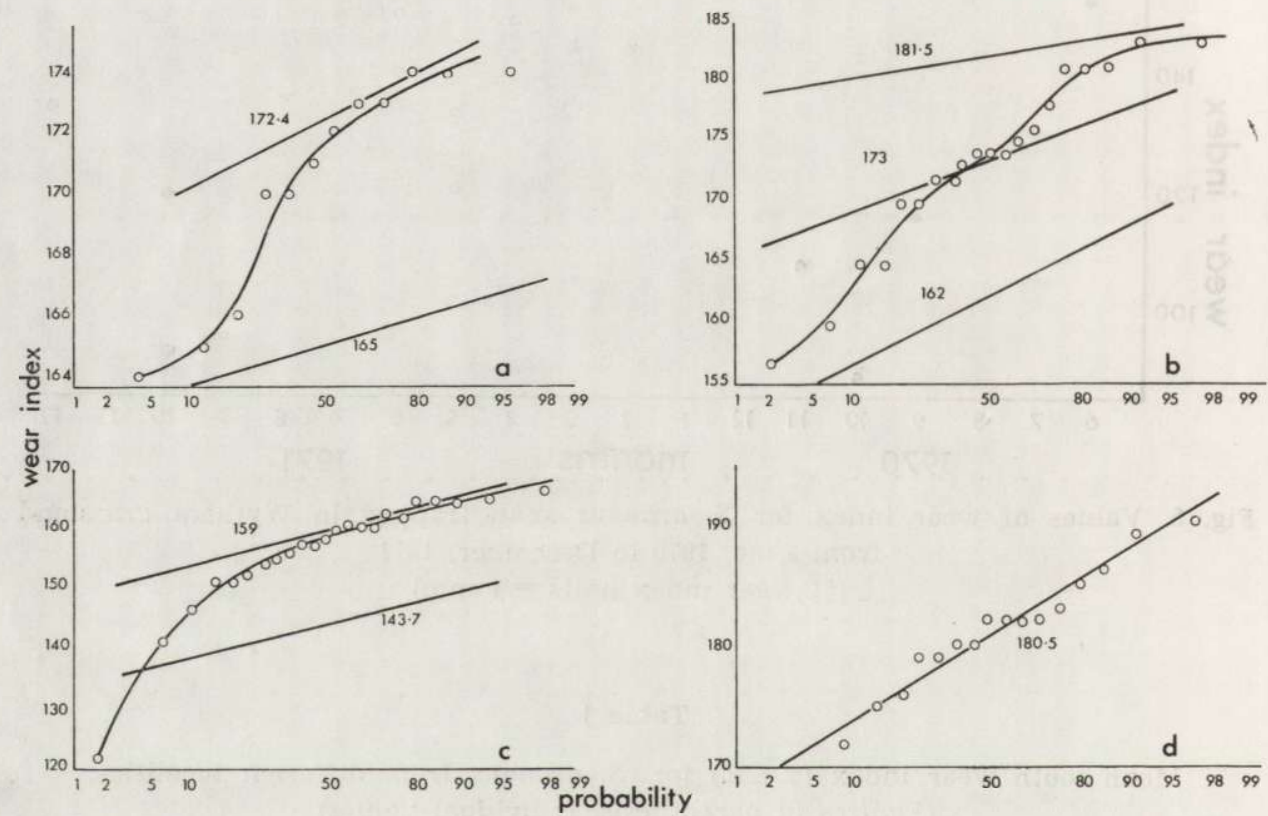

Fig. 6. Cohort analysis of $S$. araneus samples from, (a) Bardsey Island, N. Wales; (b) Odiham, Hants; (c) Maer Hills, Staffs; (d) Wytham, Oxford.

April. Breeding appears to be relatively synchronous; during the present study 19 of 22 females were pregnant or lactating during May (Table 2). A similar pattern appears to hold in the case of the pigmy shrew, although Crowcroft (1951) suggests that breeding may commence and end earlier in this species.

During 1970 on Upper Seeds, juvenile $S$. minutus were first live trapped during April and juvenile $S$. araneus in June. No juvenile $S$. minutus were caught for the first time after August whereas $6 \mathrm{~S}$. araneus were 
caught for the first time in September. In 1971 juveniles of both species were first trapped in May and no new ones caught after August, it would thus appear that breeding is relatively synchronous between the two species.

Table 2

Seasonal variation in sexual condition snap-trapped specimens.

\begin{tabular}{|c|c|c|c|c|c|c|c|}
\hline \multicolumn{8}{|c|}{ S. araneus } \\
\hline \multirow{2}{*}{ Date } & \multicolumn{3}{|c|}{ Males } & \multicolumn{4}{|c|}{ Females } \\
\hline & B. & N.B. & Y.Y. & L. & P. & N.B. & Y.Y. \\
\hline January & - & 5 & - & - & - & 9 & - \\
\hline February & 3 & 6 & 一 & - & - & 4 & - \\
\hline March & 6 & 2 & - & - & 1 & 6 & - \\
\hline April & 4 & 1 & - & - & - & 4 & - \\
\hline May & 11 & 1 & 2 & 2 & 17 & 3 & - \\
\hline June & 9 & - & 1 & - & 2 & 14 & 3 \\
\hline July & 2 & - & 3 & - & - & 4 & 4 \\
\hline August & 1 & - & 9 & 2 & - & 1 & 10 \\
\hline September & - & - & 12 & - & - & 1 & 10 \\
\hline October & - & 3 & 24 & - & 1 & - & 21 \\
\hline November & - & - & 14 & - & - & 一 & 9 \\
\hline December & - & - & 12 & - & - & - & 11 \\
\hline
\end{tabular}

\begin{tabular}{|c|c|c|c|c|c|c|c|}
\hline \multirow{2}{*}{ Date } & \multicolumn{3}{|c|}{ Males } & \multicolumn{4}{|c|}{ Females } \\
\hline & B. & N.B. & Y.Y. & L. & P. & N.B. & Y.Y. \\
\hline January & 4 & 4 & - & - & - & 9 & - \\
\hline February & 4 & - & - & - & - & 2 & - \\
\hline March & 6 & 2 & - & - & - & 2 & - \\
\hline April & 2 & - & - & - & - & 6 & - \\
\hline May & 6 & - & - & 1 & 1 & 2 & - \\
\hline June & 3 & - & 5 & - & 2 & 2 & 4 \\
\hline July & 1 & - & 4 & - & - & 1 & 4 \\
\hline August & - & - & 8 & - & - & - & 4 \\
\hline September & - & - & 9 & 1 & - & - & 8 \\
\hline October & - & - & 4 & - & - & - & 6 \\
\hline November & - & - & 7 & - & - & - & 5 \\
\hline December & - & - & 7 & - & - & - & 6 \\
\hline
\end{tabular}

B. = Breeding; N.B. = Nonbreeding; Y.Y. = Young of the year; L. = Lactating; $\mathrm{P} .=$ Pregnant

Of the 22 pregnant $S$. araneus dissected during the present study, 5 showed regression of single embryos, altogether 5 embryos out of 135 ; mean litter size in May was $7.5(\mathrm{n}=15)$, and a single pregnant female trapped in October carried a single embryo. 


\section{Longevity and Survival}

Table 3 shows the months of first capture and subsequent fate of early and late season young. The ages expressed in days are based on

Table 3

Percentage mortalities, months of first capture and subsequent recaptures, of early and late born, live trapped shrews in Wytham grassland.

\section{S. araneus}

\begin{tabular}{|c|c|c|c|c|c|c|c|c|c|c|c|c|c|c|c|c|c|c|c|}
\hline \multirow{2}{*}{$\begin{array}{c}\text { Age } \\
\text { in } \\
\text { Days }\end{array}$} & \multicolumn{3}{|c|}{ Months: } & \multicolumn{7}{|c|}{ May 1970 - February 1971} & \multicolumn{9}{|c|}{ Months: May 1971 - January 1972} \\
\hline & 5 & 6 & 7 & 8 & 9 & 10 & 11 & 12 & 1 & 2 & 5 & 6 & 7 & 8 & 9 & 10 & 11 & 12 & 1 \\
\hline 21 & & 2 & - & 5 & 6 & - & - & - & - & - & 2 & 7 & 2 & 2 & - & - & - & - & - \\
\hline 51 & & & 2 & - & - & 4 & - & - & - & - & & - & 4 & 2 & 2 & - & - & - & - \\
\hline 81 & & & & 2 & - & - & 4 & - & - & - & & & - & 3 & 2 & 2 & - & - & - \\
\hline 111 & & & & & 2 & - & - & 4 & - & - & & & & - & 3 & 2 & 2 & - & - \\
\hline 141 & & & & & & 2 & - & - & 3 & - & & & & & - & 3 & 2 & 2 & - \\
\hline 171 & & & & & & & 2 & - & - & 2 & & & & & & - & 2 & 2 & 2 \\
\hline 201 & & & & & & & & 2 & - & - & & & & & $y$ & & - & 1 & 2 \\
\hline 231 & & & & & & & & & 2 & - & & $\because$ & & & & & & - & 1 \\
\hline 261 & & & & & & & & & & 2 & & 1 & & & & & & & - \\
\hline
\end{tabular}

Mortality during the first 6 months of life: Weaning $-2 \mathrm{mo}-4 \mathrm{mo}-6 \mathrm{mo}$. Assuming all losses due to mortality:

Resicent mortality (excl. individuals trapped during only 1 session):

$$
7 \% \quad 8 \% \quad 25 \%
$$

\section{S. minutus}

\begin{tabular}{|c|c|c|c|c|c|c|c|c|c|c|c|c|c|c|c|c|c|c|c|c|c|}
\hline \multirow{2}{*}{$\begin{array}{c}\text { Days } \\
\text { in } \\
\text { Age }\end{array}$} & \multicolumn{11}{|c|}{ Months: April 1970 - February 1971} & \multicolumn{10}{|c|}{ Months: April 1971 - January 1972} \\
\hline & 4 & 5 & 6 & 7 & 8 & 9 & 10 & 11 & 12 & 1 & 2 & 4 & 5 & 6 & 7 & 8 & 9 & 10 & 11 & 12 & 1 \\
\hline 21 & 3 & 2 & - & 4 & 4 & - & - & - & - & - & - & - & 3 & 2 & 3 & 8 & - & - & - & - & - \\
\hline 5 & & 3 & 2 & - & 4 & 3 & - & - & - & - & - & & & 3 & 2 & 3 & 2 & - & - & - & - \\
\hline 81 & & & 3 & 1 & - & 4 & 3 & - & - & - & - & & & & 3 & 2 & 2 & - & - & - & - \\
\hline 111 & & & & 2 & 1 & - & 3 & 2 & - & - & - & & & & & 1 & 2 & 1 & - & - & - \\
\hline 14 & & & & & 1 & 1 & - & 1 & 2 & - & - & & & & & & - & 2 & 1 & - & - \\
\hline 1 & & & & & & - & 1 & - & 1 & 2 & & & & & & & & - & 1 & 1 & - \\
\hline 2 & & & & & & & - & 1 & - & 1 & 2 & & & & & & & & - & 1 & - \\
\hline & & & & & & & & - & 1 & - & 1 & & & & & & & & & - & - \\
\hline 26 & & & & & & & & & - & 1 & - & & & & & & & & & & - \\
\hline 291 & & & & & & & & & & - & 1 & & & & & & & & & & \\
\hline
\end{tabular}
Mortality during the first 6 months of life: Weaning $\frac{-2}{38 \%}$ mo. $\frac{-4}{56 \%}$ mo. $\frac{-6}{38 \%}$ mo.
Assuming all losses due to mortality:

Resident mortality (excl. individuals trapped during only 1 session):

$18 \% \quad 56 \% \quad 38 \%$

the assumption that the age at first capture is equal to the age at weaning (i.e. 21 days, $\mathrm{Cr}$ ow croft, 1957). This is likely to be an underestimate of the actual value since animals weaned on or around the 
last day of trapping will be twice as old when first caught as those weaned at the commencement of a trapping period.

The survivorship curves for the two cohorts of each species (Fig. 7) include a pre-weaning mortality determined by the difference between the theoretical number of young produced on the grid and the actual number trapped. When the numbers on which the percentage mortality figures in Table 3 are based, are tested by means of a $\mathrm{Chi}^{2}$ test, then the number of resident individual $S$. araneus dying in the three periods is not significantly different. In the case of $S$. minutus, however, peak mortality between months 2 and 4 of life is significantly greater than that occurring during the other two periods $(p=0.0138)$. In addition, total mortality in $S$. minutus is higher $(p=0.002)$ than that of $S$. araneus over this period. These figures suggest that population structure in the two species is different, mortality in the common shrew occurring earlier

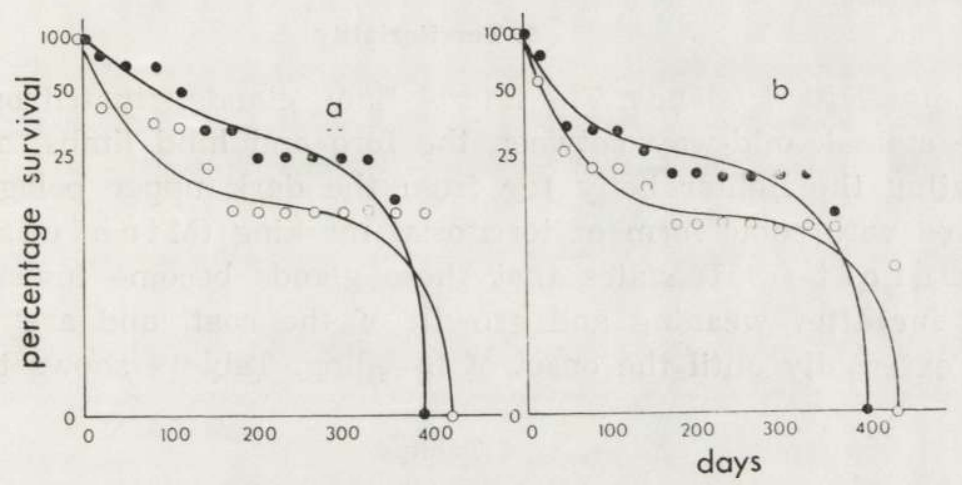

Fig. 7. Survivorship curves of (a) S. araneus and (b) S. minutus in Wytham grassland, $\bigcirc$ early born cohort,

late born cohort.

in life at the dispersal phase, whereas mortality in the pigmy shrew occurs later and involves the death of resident individuals. An alternative explanation might be that dispersal occurs later (between months 2 and 4 of life) in the pigmy shrew.

The survival of the nomadic portion of the population is difficult to assess but may depend upon the ability of individuals to find and establish suitable home ranges. This suggestion is supported by the fact that two juvenile $S$. araneus which re-colonised the quadrat in June, 1971, survived to breed the following spring.

Taking into consideration small sample size and combining the data for the two years, a life table for each species can be constructed based on the following assumptions: that breeding is synchronous with two peaks during May/Jure and August/September; that the average litter 
size for the first period is 7.4 (Crowcroft, 1957) and 5.1 for the second (Brambell, 1935); and finally, that all losses are due to mortality. The latter assumption is reasonable in that failure to recapture individuals after a long time period indicates that from the point of view of the area under study the animals are effectively dead.

Performing such a life table calculation for S. araneus, it would appear that the late born cohort is reproducing and replacing itself (Intrinsic rate of increase, $R_{o}=1.14$ ) whilst the early born cohort is failing to do so $\left(R_{o}=0.249\right)$, which suggests that the late born young in this area are most important in population maintenance.

In the case of the pigmy shrew, litter size is assumed to be 6 (Crow croft, 1957) and all losses are assumed to be due to mortality as outlined above. Here again, the late born cohort appears to be the most important in population maintenance $\left(R_{o}=1.2\right)$ whilst the early born cohort is less.

\section{Territoriality}

a. Lateral flank glands. The lateral flank glands situated on the sides of the animal, mid-way between the fore and hind limbs, on the line separating the lighter belly fur from the dark upper pelage, may be involved with some form of territorial marking ( $\mathrm{M} \mathrm{i} \mathrm{chiels} \mathrm{on,} \mathrm{1966).}$ Crowcroft (1957) states that these glands become invisible in the dense fur after weaning and growth of the coat, and are not visible again externally until the onset of breeding. Table 4 shows that during

Table 4

External visibility of the lateral flank glands of $S$. araneus.

\begin{tabular}{|c|c|c|c|c|c|c|c|c|c|c|c|c|c|}
\hline Month & & 1 & 2 & 3 & 4 & 5 & 6 & 7 & 8 & 9 & 10 & 11 & 12 \\
\hline \multirow{2}{*}{ Males } & V & 3 & 2 & 2 & 1 & 1 & 4 & 2 & - & - & - & - & - \\
\hline & $\mathrm{N}$ & 2 & 7 & 6 & 4 & 5 & 5 & - & 1 & - & - & 1 & - \\
\hline \multirow{2}{*}{ Females } & V & 1 & - & - & 3 & 2 & 6 & 1 & - & - & - & - & - \\
\hline & $\mathrm{N}$ & 4 & 4 & 7 & 1 & 3 & 3 & 3 & 3 & 1 & 1 & - & - \\
\hline Juveniles & V & - & - & - & - & - & - & - & 2 & 2 & 3 & 11 & 12 \\
\hline Total & $\mathrm{N}$ & $\overline{1}$ & $\overline{18}$ & $\overline{10}$ & - & $\overline{14}$ & 4 & 12 & 19 & 20 & 18 & 12 & 11 \\
\hline
\end{tabular}

V - Lateral flank gland visible externally; N - Lateral flank gland not visible externally.

the present study half of the juveniles (23 out of 46) showed some signs of flank gland activity during November/December, but that prior to the onset of breeding it was much less active. This early winter period of activity corresponds to the establishment of winter home ranges by the young of the year (see below) and this may by taken as support for the 
contention that these glands are involved in the marking of home ranges.

b. Trap revealed ranges. The work of $\mathrm{Mich}$ iels on (1966) Shillito $(1960)$ and B uckner $(1966,1969)$ has shown that for much of the year, at least, shrews have restricted trap revealed home ranges (hereafter described as home ranges). Since these are relatively exclusive they may be considered more as territories.

Table 5 shows the number of captures involving more than one, and only one, animal at a particular trap point. From this table, it might be concluded that in this habitat the individual ranges are relatively discrete, however, although the home ranges for $S$. araneus are mutually exclusive for the period from October to March; during October, 1970, and from June to October, 1971, juveniles seem to roam over larger less discrete areas. In the case of $S$. minutus the pattern is similar although a certain amount of overlap occurred throughout the winter as well.

Table 5

Nos, of captures involving more than one individual at a single trap point, in any one trapping period.

\begin{tabular}{lrrrc}
\hline & Oct.-Dec. & Jan.-Mar. & Apr.-June & July-Sept. \\
\hline $\begin{array}{l}\text { S. } \text { araneus } \\
\text { multiple cap. }\end{array}$ & 5 & 3 & 0 & 6 \\
single cap. & 133 & 125 & 48 & 87 \\
$\begin{array}{l}\text { S. minutus } \\
\text { multiple cap. }\end{array}$ & 3 & 3 & & \\
single cap. & 109 & 115 & 59 & 4 \\
\hline
\end{tabular}

Home ranges can be calculated from the area covered by those traps in which an animal is caught, plus a boundary strip, measured by multiplying the periphery of the trap revealed range by half the distance separating trap points. In the case of $S$. araneus taking that period when ranges are relatively discrete then values of $0.08324 \mathrm{Ha}(n=17)$ and $0.1074 \mathrm{Ha}(\mathrm{n}=23)$, for November/December and January/February/March respectively are obtained. For $S$. minutus values of $0.1718 \mathrm{Ha}(\mathrm{n}=10)$ and $0.1435(n=17)$ are obtained for the corresponding time periods. It is of interest to note that home ranges of the smaller species ( $S$. minutus) are almost twice the size of $S$. araneus home ranges, a result confirming the findings of $\mathrm{Mich}$ iels on (1966).

\section{DENSITY ESTIMATIONS}

The estimation of shrew densities poses problems unlike those for small rodents. The recapture rate with live traps is extremely high; even 
during peak population densities all shrews trapped during any one period were caught within the first four days of trapping. During the winter months the population appears quite stable with little movement of animals on or off the grid, whilst during the summer the population appears to be composed of both resident and nomadic individuals.

In view of the high recapture rate during the periods of population stability, the individuals trapped on the grid may be taken as the total population. For other periods of the year B u c kn e r (1969) suggests that the densities for a fixed area should be estimated by adding to the resident numbers, a figure determined by dividing the grid area by the mean daily catch of vagrants. Such a procedure was adopted by the present author.

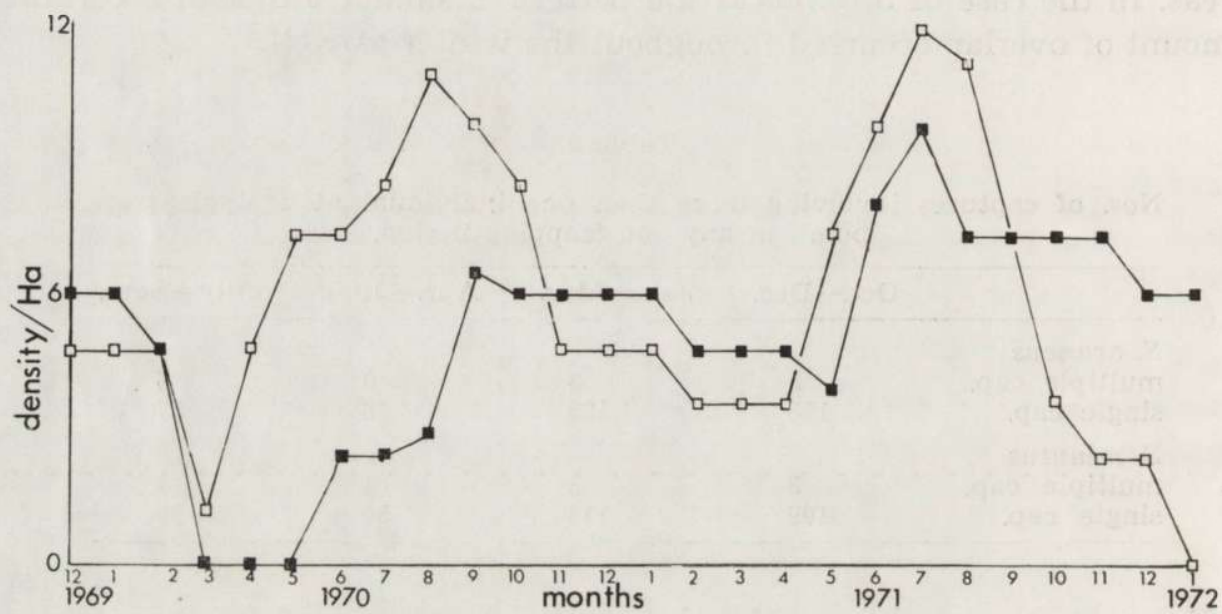

Fig. 8. Shrew densities in Wytham grassland,

S. araneus,

S. minutus.

In determining the density of residents Buckner divides the numbers trapped by a corrected grid size which includes the area encompassed by the traps, and a boundary strip determined by the cruising radius of the species. During six of the twenty-six monthly trapping periods conducted for the present study, a line of traps was placed fifteen metres away, round the edge of the grid to assess movements away from the grassland into the surrounding woodland and arable land. No pigmy shrews were caught in this line of traps during any of the periods but a number of marked $S$. araneus were. In two individual cases the number of captures made outside the grid was higher than the number made on the grid, but the total captures of other marked individuals was extremely small (12 in all). Thus, the boundary strip added to the area of the grid for the calculation of densities was taken as being the perimeter of the 
grid multiplied by half the distance separating this outer line from the grid itself, i.e. $7.5 \mathrm{~m}$. The corrected area of the grid thus becomes $0.813+$ $+0.025=0.838 \mathrm{Ha}$. Individuals numbered 16 and 30 were considered as balancing the infrequent capture of grid residents in the boundary line and were therefore dropped from the calculation. Vagrants were taken as those individuals caught during only one trapping period.

Figure 8 shows the density estimations. In the case of $S$. araneus, it can be seen that stable densities of approximately $6 / \mathrm{Ha}$ are found from September through to December followed by a gradual decline from January through to the appearance of the juveniles in June. In 1971 peak densities were found in July followed by a rapid decline to the prebreeding level.

In the case of $S$. minutus the winter densities seen from November to March in 1969 and 1970 are slightly lower that those of $S$. araneus. In addition the population appeared to be at an extremely low level at the end of the study. The peak densities in this species appeared in both years in August, slightly earlier in 1970. During this period the density is much higher than that of $S$. araneus, resulting in a more marked decline to the winter level.

\section{DISCUSSION AND CONCLUSIONS}

The results of the present study parallel those of $\mathrm{Crowcroft}$ (1957), Shillito (1963) and Buckner (1969) in Britain, that of Michielson (1966) in Holland and that of Borowski \& Dehnel (1953) in Poland; in that the overlap between generations is small. It is worthy of note that the actual role played by the early and late born young in the maintenance of shrew populations is still unclear, and a more detailed study is necessary to elucidate this point. The method of ageing described in this paper may be of use in this respect.

The reasons for the totality of the summer/autumnal mortality of adults are unclear but may be linked with the factors responsible for decreased litter size. S t e in (1954) suggested that due to an sinability " of old animals to moult, the absence of a winter coat might lead to instability of thermal balance. This idea seems inadequate for two reasons, firstly, the death of the adult generation occurs prior to the onset of winter temperatures, and secondly, old individuals may be encountered which appear to be undergoing a normal autumnal moult (P e r n e t t a, 1976a) as distinct from the old age moult described by B orowski (1963). B or ow ski \& Dehnel (1959) have suggested that death may be due to an overloading of parasites, a conclusion supported by $\mathrm{K}$ is i e- 
lew ska (1961, 1963). C r ow c r of t's suggestion "that a general food shortage resulting in the death of worn out individuals " is probably incorrect since the major mortality occurs before the onset of winter. Negative production in $S$. araneus indicative of food shortage occurs after the autumnal mortality of adults (P e r n e $t \mathrm{t}$ a, 1976c).

$\mathrm{Spannh}$ of (1952) considered that worn teeth may lead to reduced food intake and hence starvation, which is not unreasonable since the wear of important food handling teeth is here shown to be quite intense (Fig. 4). Reduced dental efficiency leading to increased prey handling times and hence reduced food intake, and a depletion of fat reserves may make animals susceptible to food shortages lasting a few days or even hours.

In view of her findings Michiels on (1966) concluded that there existed no competition between the two species for space, a contention supported by the present data. She suggests that competition between the two species might occur in terms of diet, this suggestion is refuted by the dietary study mentioned above (P ernetta, 1976b) and thus one must conclude that competition between these two closely related sympatric species is at a minimum. What is apparent in all studies to date is that competition between members of the same species of shrew appears to operate on a spatial basis, young dispersing from the territory of the female and attempting to establish territories of their own. It may well be that the majority of young fail to establish such territories and thus perish, in much the same way that young tawny owls are presumed to do (S o u the rn, 1972).

In conclusion it might be stated that these animals present many unique and interesting features which would repay further study on a larger scale and more extended basis.

Acknowledgements: I am indebted to the Christopher Welch Biological Trust for the provision of financial support from 1969 to 1972 , and to Professor J. W. S. Pringle and Dr. J. Phillipson for permission to work in the Department of Zoology and Animal Ecology Research Group, respectively. My thanks must also go to Dr. M. J. Coe for his unstinting support and enthusiasm during the course of this research, and for reading the manuscript. The many members of the Ecology group have my thanks for their help and comments, critical and otherwise which contributed greatly to this research and paper, in particular Dr. P. H a ndford, Dr. R. A b e l and Dr. G. A. C. Bell. In addition, Mr. D. K e m p s o n, Mr. K. $\mathrm{Marsl}$ a nd and Miss $\mathrm{H}$. Cook provided valuable technical assistance at various stages. Finally, my thanks must go to Dr. H. N. S outhern, Dr. K. Southern, and Mr. C. Eito n, F. R. S., who have stimulated and encouragea my interest in animal ecology over many years.

\section{REFERENCES}

1. A d a m s L. E., 1910: A hypothesis, as to the cause of the autumnal epidemic of the common and lesser shrew, with some notes on their habits. Mem. Proc. Manchr. Lit. Phil. Soc., 54, 10: 1-13. 
2. A d a m s L. E., 1912: The duration of life of the common and the lesser shrew with some notes on their habits. Mem. Proc. Manchr. Lit. Phil. Soc., 56, 7: 1-10.

3. Bishop I. R. \& Dela n y M. J., 1963: Life histories of small mammals in the Channel Island in 1960-61. Proc. zool. Soc. Lond., 141: 515-526.

4. B r a mbell F. W. R., 1935: Reproduction in the common shrew (S. araneus L.). Phil. Trans., B, 225: 1-62.

5. Brambell F. W. R. \& Hall K., 1937: Reproduction in the lesser shrew (S. minutus L.). Proc. zool. Soc., Lond., 1936: 957-969.

6. Borowski S., 1963: Old-age moult in the common shrew Sorex araneus Lin n a u s, 1758. Acta theriol., 7, 19: $374-375$.

7. Borowski S. \& Dehnel A., 1953: Materiały do biologii Soricidae. Annls Univ. M. Curie-Skłodowska, C 7: 305-448.

8. Buchalczyk A., 1972: Seasonal variations in the activity of shrews. Acta theriol., 17, 17: 221-243.

9. Buckner C. H., 1966: Populations and ecological relationships of shrews in Tamerack bogs of Southwestern Manitoba. J. Mammal., 47: 181-194.

10. Buckner C. H., 1969: Some aspects of the population ecology of the common shrew, Sorex araneus, near Oxford, England. J. Mammal., 50: 326-332.

11. Chitty D. \& Kempson D. A., 1949: Prebaiting small mammals and a new design of live traps. Ecology, 30: 536-542.

12. Conaway C. H., 1952: The life history of the Water Shrew (Sorex palustris navigator). Amer. Midl. Nat., 48: 219-248.

13. Crowcroft P., 1951: Live trapping British shrews. J. Mammal., 32: 355356.

14. Crowcroft P., 1945: The daily cycle of activity in British shrews. Proc. zool. Soc. Lond., 123: $715-729$.

15. Crowcroft P., 1956: On the life span of the common shrew (S. araneus L.) Proc. zool. Soc. Lond., 127: 285-292.

16. Crow croft P., 1957: The life of the shrew. Methuen: 1-166. London.

17. Gębczyński M., 1965: Seasonal and age changes of the metabolism and activity of Sorex araneus Linn a e s, 1758. Acta theriol., 10, 22: 303-331.

18. H a r ding J. P., 1949: The use of probability paper for the graphical analysis of polymodal frequency distributions. J. Mar. Biol. Ass. U. K., 28: 141-153.

19. J a n ský L. \& H a nák V., 1960: Aktivität der Spitzmäuse unter natürlichen Bedingungen. Säugetierkdl. Mitt., 8: 55-63.

20. K is i elewska K., 1961: Circulation of tapeworm of Sorex araneus araneus L. in biocenosis of Białowieża National Park. Acta parasit. pol., 9, 24: 331-369.

21. K is ielew ska K., 1963: Food composition and reproduction of Sorex araneus in the light of parasitological research. Acta theriol., 7, 9: 128-153.

22. Michielson N. C., 1966: Intraspecific and interspecific competition in the shrews Sorex araneus L. and Sorex minutus L. Archs. Néerl. Zool., 17, 1: 73-174.

23. P ernett a J. C., 1973 a: D. Phil. Thesis. Elton Library, Oxford.

24. Pernetta J. C., 1973b: The ecology of Crocidura suaveolens cassiteridum (H i n t o n) in coastal habitat. Mammalia, 37, 2: 241-256.

25. Pernetta J. C., 1976a: A note on the moult of Sorex araneus (L) and Sorex minutus (L.) with observations on the patch moults of Crocidura suaveolens. J. Zool., Lond., 179: 216-219.

26. Pernetta J. C., 1976b: Diets of the shrews Sorex araneus L. and Sorex minutus L. in Wytham grassland. J. Anim. Ecol., 45: 899-912. 
27. Pernetta J. C., 1976c: The bioenergetics of shrews in Wytham grassland. Acta theriol., 21, 33: 481-497.

28. Pucek Z., 1969: Trap response and estimation of the numbers of shrews in removal catches. Acta theriol., 14: 403-426.

29. R o o d J. P., 1965: Observations in population structure, reproduction, and moult of the Scilly shrew. J. Mammal., 46: 426-433.

30. Schubarth H., 1958: Zur Variabilität von Sorex araneus araneus L. Acta theriol., 2: 175-202.

31. Shillit o J., 1960: Unpubl. thesis Univ. Exeter. Quoted Linn, 1965.

32. Shillito J., 1963: Field observations on the growth, reproduction and activity of a woodland population of the common shrew, Sorex araneus L. Proc. zool. Soc. Lond., 140: 99-114.

33. Southern H. N., 1972: The natural control of a population of Tawny Owls (Strix aluco). J. Zool., Lond., 162: 197-285.

34. Spannhof L., 1952: Spitzmäuse. Die Neue Brehm-Bucherei, No. 48, 1- 44.

35. Stein G. H. W., 1954: Materialien zur Haarwechsel deutscher Insectivoren. Mitt. zool. Mus. Berl., 30: $12-34$.

Accepted, March 9, 1977.

John C. PERNETTA

\section{EKOLOGIA POPULACYJNA RYJOWEK ZAMIESZKUJĄCYCH MURAWY}

\section{Streszczenie}

Przedstawiono wyniki 25-miesięcznych odłowów Sorex araneus i Sorex minutus w pułapki żywołowne w środowisku muraw w Wytham (południowa Anglia) oraz dane z 18 miesięcy odłowów w zatrzaski na sąsiednim, podobnym terenie (Ryc. 1, 2). Opisano aktywność dwóch gatunków Sorex w terenie (Ryc. 3), oraz wyliczono różne parametry populacyjne, takie jak: aktywność płciowa (Tabela 2), wielkość miotu, zagęszczenie (Ryc. 8) i rozmieszczenie. Do określania wieku zwierząt zastosowano oceny ścierania się dolnych siekaczy (Ryc. 4). Zilustrowano stopniowe ścieranie się tych zębów, na przykładzie zwierząt lowionych w zatrzaski (Ryc. 5), a także dokonano podziału młodych, tegorocznych ryjówek, na osobniki urodzone wcześniej i później w danym roku (Ryc. 6). W Tabeli 1 pokazano różne stopnie starcia siekaczy u osobników pochodzących z różnych miejsc. Przeżywalność wcześniej i później urodzonych młodych z obu gatunków pokazuje Ryc. 7, a ich tabele życia przedstawione zostały w Tabeli 4 . 